\title{
Small Intestinal Leiomyoma
}

National Cancer Institute

\section{Source}

National Cancer Institute. Small Intestinal Leiomyoma. NCI Thesaurus. Code C7725.

A benign smooth muscle neoplasm arising from the small intestine. It is characterized by the presence of spindle cells with cigar-shaped nuclei, interlacing fascicles, and a whorled pattern. 